\title{
Containment and connectivity in Dutch urban systems: A network-analytical operationalization of the three-systems model.
}

Ate Poorthuis, Singapore University of Technology and Design

Michiel van Meeteren, Loughborough University

Published as: Poorthuis, A. \& M. van Meeteren. (2019). Containment and connectivity in Dutch urban systems: A network-analytical operationalization of the three-systems model. Tijdschrift voor Economische en Sociale Geografie. [Online First] http://doi.org/10.1111/tesg.12391.

\begin{abstract}
This paper discusses central methodological issues with nodalizing interaction data of urban networks to produce a state-of-the-art settlement geography of the Netherlands. We operationalize the three-systems model that understands functional settlement geographies through the interaction between the daily urban system, the central place system and the export base system. We utilize theoretically-informed selections of spatial interactions derived from travel survey data at the finely-grained postcode level. After examining the methodological challenge of the node-inclusivity dilemma, we estimate the causal mechanisms that geographically structure each system and determine which spatial interactions should be assigned to nodes (containment) and edges (connectivity). The three systems produce different regionalizations that are neither mutually exclusive nor perfectly nested. Further analysis of the multiplexity of the three systems reveals the importance of the imbricated boundaries between the urban subsystems. We argue that these interplaces deserve more attention as they are particularly sensitive to changes in urbanization trends.
\end{abstract}

Keywords: three-systems model, Netherlands, urban network analysis, spatial interaction, nodalization, node-inclusivity dilemma 


\section{INTRODUCTION}

What we commonly refer to as a 'city' is the manifestation of several underlying urban subsystems. Each subsystem derives its function from phenomena existing at very different scales. Some functions are the product of interactions in the inner city, some result from interactions on the larger scale labor or housing markets, and some might function at the level of a megaregion (Van Meeteren, 2019, cf. Saey, 1970: 260-264). As the settlement articulates all these different subsystems, depending on which system we examine, the city will take on different geometries and scales (Lang and Knox 2009). In this paper, we analyze the variable geometry of the Dutch settlement system. We do so by forgoing the attempt to capture all scales and geometries into a single territorial definition but instead adopt the three-systems model (Van Engelsdorp Gastelaars and Ostendorf 1991; Van Meeteren 2016). The three-systems model provides a multi-dimensional definition of functional urban areas and distinguishes differential geographical structuring related to the export base system, the central place system, and the daily urban system.

The Netherlands is no stranger to debates about the proper scale of the city. After decades advocating for regional, polycentric city definitions such as the Randstad (Jobse and Needham, 1988), recent debates have increasingly re-emphasized the dominance of the primate city of Amsterdam (Burger et al. 2014a, 2014b). Although these debates carry significant policy relevance (i.e. they influence the size and direction of funding streams), they often compare apples to oranges by ignoring the definitional fluidity in the geometry and scale of the city. This paper joins a growing chorus of scholars (Burger et al. 2014a, 2014b; Lambregts et al. 2006; Limtanakool et al. 2009; Van Oort et al. 2015) that use network-analytical approaches to tackle definitional problems prevalent in analyses of the Dutch urban system. If the city is indeed a space "where diverse ranges of relational webs coalesce, interconnect and fragment" as Amin and Graham (1997, p. 418), building on Dematteis (1988), argue, it is necessary to specify how and why webs of human interaction generate these coalescing socio-spatial structures and systems. 
We continue as follows. We first contextualize our research by elaborating the history of urban networks thinking in the Dutch spatial disciplines and situate our work in that tradition. We then present a detailed micro-level dataset based on a longitudinal national household travel survey (2004-2016) and discuss how we operationalize each of the three urban systems through theoretically-informed selections from this dataset. We also outline the main operational challenges associated with nodalizing a spatial field of interaction data. Thereafter, we elaborate the containment and connectivity in the settlement geographies of each urban system separately before we explore the spatial impact of the multiplexity of the three conjoined urban networks. We conclude by highlighting the importance of interplaces (Phelps 2017) for geographers and spatial planners interested in optimizing the functioning of the Dutch settlement geography.

\section{BACKGROUND: URBAN SYSTEMS AND URBAN NETWORKS}

What we understand as settlement is the product of superimposed urban layers, deposited by different agglomeration-economy regimes over time. Agglomeration-economy regimes are epoch-specific, and articulate their own distinct urbanization scale, based on a varying combination of technology, labour and capital inputs, and mobility technologies (Van Meeteren et al. 2016a). Agglomeration-economy regimes alternate between centrifugal and centripetal tendencies (Colby 1933): in some epochs being in the middle is far more important than in others. Places with long settlement histories, like the Netherlands, often gain their distinctive character in earlier agglomeration-economy regimes (Hohenberg and Lees 1994 [1985]), and subsequent regime changes might yield new geographies in which previously-distinct settlements increasingly overlap (Boussauw et al. 2018).

Debates about the scale of the city and the changing character of the Dutch urban system have preoccupied Dutch geographers and planners for generations (Zonneveld \& Verwest 2005). The notion of 'city region' ('stadsgewest') was introduced in the late 1950s to account for cities that suburbanized outside their historical confines (idem, pp. 74-77). To cope with the car mobility driven late-industrial agglomeration-economy regime of the 1960s (Van Meeteren et al. 2016a), 
the Dutch government implemented a policy of 'bundled deconcentration'. Growth centres ('groeikernen') were built to preserve open space, while accommodating the desired suburban living environments (Bontje 2001; Zonneveld \& Verwest 2005). This policy was reversed for the 'compact city' policy in the early 1980s (Bontje 2001; Van der Burg \& Dieleman 2004) to counteract the decay of inner cities that was partly attributed to the success of decentralization policy. In the mid-1990s the focus shifted to centrifugal tendencies again, as the post-industrial agglomeration economy regime emphasized dispersal and development of greenfield sites (Van Meeteren et al. 2016a). In the Netherlands, economic growth was perceived to shift from the West, the Randstad core area, to the 'half way zone' in the middle of the country, particularly on accessible highway and in-between locations (Jobse \& Needham 1988; Priemus 1998). More recently, the debate swung back again emphasizing the importance of Amsterdam, the Dutch capital city (Burger et al. 2014a; 2014b, Raspe \& Van den Berge 2017), coinciding with the agglomeration-economy regime Van Meeteren et al. (2016a) describe as 'metropolization'.

The Dutch urban-geographical tradition can be regarded an early adopter of interaction-based conceptions of (urban) space. Van Paassen (1962, p.221, paraphrased and translated from Dutch) argues that "Geographical structuring is not just the spatial manifestation of institutions and social relations but also structures space as institutions, (trans)actions, households and amenities are localized and operate in a network of spatial relations; generating spatial differentiation". What Van Paassen means with "geographical structuring" corresponds with contemporary thinking on how repeated (routine) interactions "regionalize" into recognizable spatial entities and identities (Pred1984; Van Meeteren et al. 2016a)

Dutch settlement geographies have a long history of examining such geographical structuring through relational interpretations of urbanization based on export base and central place theories (Keuning \& De Vooys 1964; De Smidt 1983). Following similar thinking, Hohenberg and Hollen Lees (1995 [1985]) also argue that the interplay between central place and export base logics ${ }^{1}$ account for the explanation of settlement geographies, formulating a 'two systems' model of settlement geography. In his oration, Van Paassen (1965) increasingly associates his ecological perspective with the Chicago school of sociology as an additional structuring mechanism of 
urbanization (Van Ginkel 1983). Accommodating this insight, Van Engelsdorp Gastelaars \& Ostendorf $(1986 ; 1991)$ expand the argument into the three-systems model, arguing that central place and export base theories are too focused on a 'productive' order to comprehensively understand the emerging post-industrial era. In addition to the two 'productive orders', they add a 'consumptive order' based on geographical structuring in the daily urban system that accounts for smaller-scale changes in the urban system. As such, the three-systems model consists of: the export base system; the central place system; and the daily urban system. Settlements will take up different positions (i.e. shapes and scales) in each of the three systems (Cortie et al. 1992; Thissen 1995, p. 61). As agglomeration-economy regimes change, the relative position of a settlement within each subsystem changes too. We will discuss the three systems and their causal mechanisms that determine geographical structuring more elaborately in section 4.

From the 1960s onwards, spatial thinkers increasingly adopt network-related concepts. Networked information technology and the Internet, and the changing practices of work and leisure associated those technologies, have long been argued to radically change the way the settlement geographies are structured (Berry 1970; Hajer \& Zonneveld 2000). The way the Dutch urban system has developed with its historic cores, and well-bounded growth centres connected by commuting, lent itself to a networked imagination. Steigenga (1972), following Lynch (1961), proposes to transform the imaginary and evolution of the Randstad from a 'ring' to a 'polycentric net' of interacting settlements. The notion of a network of interconnected action spaces visually dominates Hoekveld's (1968) interpretation of Van Paassen's (1962) relational model of society², informing empirical studies of interaction in the Dutch settlement system based using network analysis of crude data from telephone switchboards (Dietvorst \& Wever 1977) or diffusion of TV ownership (Van der Knaap 1980).

The term 'urban networks' is rejuvenated as the paradigmatic term in the mid 1980s to assemble an ambitious Dutch interdisciplinary research program that aims to tackle the shifting dynamics of urbanization in post-industrial society and propose solutions for the 1980s urban crisis (Jobse \& Needham 1988; Van Weesep \& Van der Vaart 1988). In the 1990s, urban networks as an 
expression of the 'postindustrial network economy' become increasingly common in the academic literature and the Dutch polycentric Randstad is commonly held-up as the archetypical example (Batten 1995). Concepts such as the 'network city' and 'urban networks' gradually become elevated as spatial planning doctrine in the 1990s (Bontje 2001) where they remain up until today (Priemus 2004; Van den Burg \& Dieleman 2004; Van Oort et al. 2015). Visualizations that draw lines connecting cities are increasingly common in Dutch spatial plans in the 1990s (Zonneveld \& Verwest 2005), and network-based thinking becomes ubiquitous among spatial thinkers and professionals. Cities lobby to be included as a literal dot in the urban network as the spoils of regional policy might be conditional to 'being part of the network' (idem).

Nevertheless, questions about the functional scale of network cities and urban networks remain (Atzema 1999). Moreover, while Dutch planning is talking about urban networks in the 1990s, actual network-analytical empirical studies (e.g. Van der Laan 1998) were scarce due to limited, often proprietary, data compounded by the contemporary specialized state of GIS that was not focused on relational ontologies (Burger et al. 2014a). Although new nationally-coordinated data systems lead to a renewed wave of mobility studies in the early 2000s (e.g. Schwanen et al. 2001; Lambregts et al. 2006), theory development on urban networks in the Netherlands preceded large-scale empirical testing with graph-theoretical methods by more than a decade. Resultantly, operationalization, where theoretical categories are matched to operational definitions that allow empirical corroboration, has long been an afterthought. Therefore we will focus on an overdue network-analytical operationalization of the three-systems model.

\section{DATA AND METHODOLOGY}

Depicting a phenomenon as a network is an act of representation. A network consists of nodes that are connected by edges and thus adopting this mode of representation is particularly wellsuited to bring properties of the phenomenon related to connectedness in view. Each of the three systems emerge from social interactions and, on face value, this creates a good theoretical fit with a network perspective. Nevertheless, representing urban systems as nodes and edges requires careful operationalization. 
The dataset used in this paper is based on the Dutch household travel survey, which is conducted yearly and includes $\sim 40,000$ respondents per year ${ }^{3}$. Respondents are asked to provide, in addition to demographic data, a detailed account of their trips on a particular day. The information recorded for each trip includes the start and end point (at the postal code level) as well as the purpose of the trip (e.g. commuting, shopping, social visit etc.). The postal code serves as the 'basic' spatial unit (Openshaw 1977) from which further aggregations are made in subsequent analyses. We combine 14 years of survey data (2004 to 2017) in order to increase the number of observations for trips between sparsely populated postal codes. In total this yields a total of 1.2 million observed trips, when weighted to be representative for the entire population this creates an average of 29.4 million trips per day .

The spatial expression of the resulting dataset is a complex 'tangled spaghetti' of interactions (Harris et al. 2016). The task at hand is to isolate the geographical structures associated with the three systems. This requires careful operationalization as each of the three systems has to be calculated from different theoretically-informed selections from this travel dataset. After the relevant interactions for each system, specified one by one in the next section, we still need to define which part of that interaction is represented as 'node' and which part is represented as 'edge'. A process that generates two additional methodological conundrums: the nodalization of spatial fields and the unlikeliness of nestedness of nodes in different systems.

Nodalization of an aggregated dataset of spatial interactions is the process of carving out the part of that data is represented as 'node' that defines the areal footprint where the geographical structuring takes place (Van Meeteren et al. 2016b). Nodalization can be done inductively, for instance by using algorithmic techniques to 'discover' stabilizations in the network. These stabilizations are then represented as regions within which interactions are most cohesive (e.g. Verhetsel et al. 2018). However, this method makes it difficult to establish causes of this cohesiveness. Therefore, we complement these algorithmic techniques with deductive reasoning that commences from the causal mechanisms underlying the three systems. The node then 
represents a region where relative containment of the causal mechanism associated with the urban system, the knot in the dense webs of interaction, is most prevalent. Edges then represent interactions, connectivity, between the various nodes in the urban subsystem and the whole network of nodes and edges represents the subsystem as a whole.

As all three causal mechanisms of the three systems model are the product of geographical structuring, executing nodalization in a theoretically responsible manner requires walking a difficult methodological tightrope. We cannot simply assume that geographical structuring neatly coincides with either morphological or administrative urban structure (Burger et al. 2014a; Poorthuis 2018; Shelton \& Poorthuis 2019). Spatially-articulated human interactions tend to exhibit field distributions (Van Meeteren et al. 2016b; Van Meeteren \& Poorthuis 2018). Fields are 'theoretically continuous [spatial] distributions with a very rapid fall-off near their centre and a very slow, almost asymptotic fall-off at their outer ranges' (Haggett 1965, pp. 40-41). Practically speaking, defining discrete regions, or nodes, is incongruous with field distributions. The outer range of influence of a field will be geographically much further away than the average or median. If one is too inclusive, the size of the functional region will be determined by outliers negating any practical use of the analysis. It is for this reason that in central place analysis, outliers have traditionally not been considered to demarcate catchment areas (Buursink 1971; Van Meeteren \& Poorthuis 2018). Conversely, network analysis can be very sensitive to excluding those outliers. If one overlooks a determining interaction in the periphery of a field, the whole matrix of centralities within the network as a whole could change (Chisholm 1975, pp. 104-105). As such, nodalizing a spatial field is a balancing act we term as the node inclusivity dilemma. Resolving the dilemma needs a theoretical basis and much analytical utility can be derived from basing the cutoff point between 'node' and 'edge' on a theoretically relevant distinction. The outliers will then be included in the edge and still help determine how relations between nodes are structured, but will no longer define the spatial demarcation of the node.

Additionally, the three systems used here are based on different spatial processes and thus it is nearly impossible that the spatial expressions of the subsystems are nested (Saey 1970, pp. 261- 
262). This is unfortunate as the assumption of nestedness, where networks fit into smaller networks in a matrushka doll fashion, is not just prevalent in urban systems research (Neal 2012), it also simplifies analysis tremendously (Nystuen \& Dacey 1961). When we bring the findings of the three systems together, this problem of nestedness of elaborated further.

\section{KNOTS INTO NODES, SPECIFYING THE URBAN SYSTEM IN NETWORK-ANALYTICAL TERMS}

The three-systems model is premised on the existence of multiple interlocking causal mechanisms that stabilize functional settlement geographies. While interlocked, these causal mechanisms are conceptually and empirically distinguishable. Although the idea of 'three logics' is certainly not exhaustive (Van Meeteren 2016), central place systems, export base systems and daily urban systems are produced by well-described causal mechanisms rooted in human interactions in space. To operationalize these mechanisms, for each system we specify a different selection of interaction data, a different definition of what is to be considered node, how this node is articulated spatially, and what the edges between nodes represent (summarized in Figure 1).

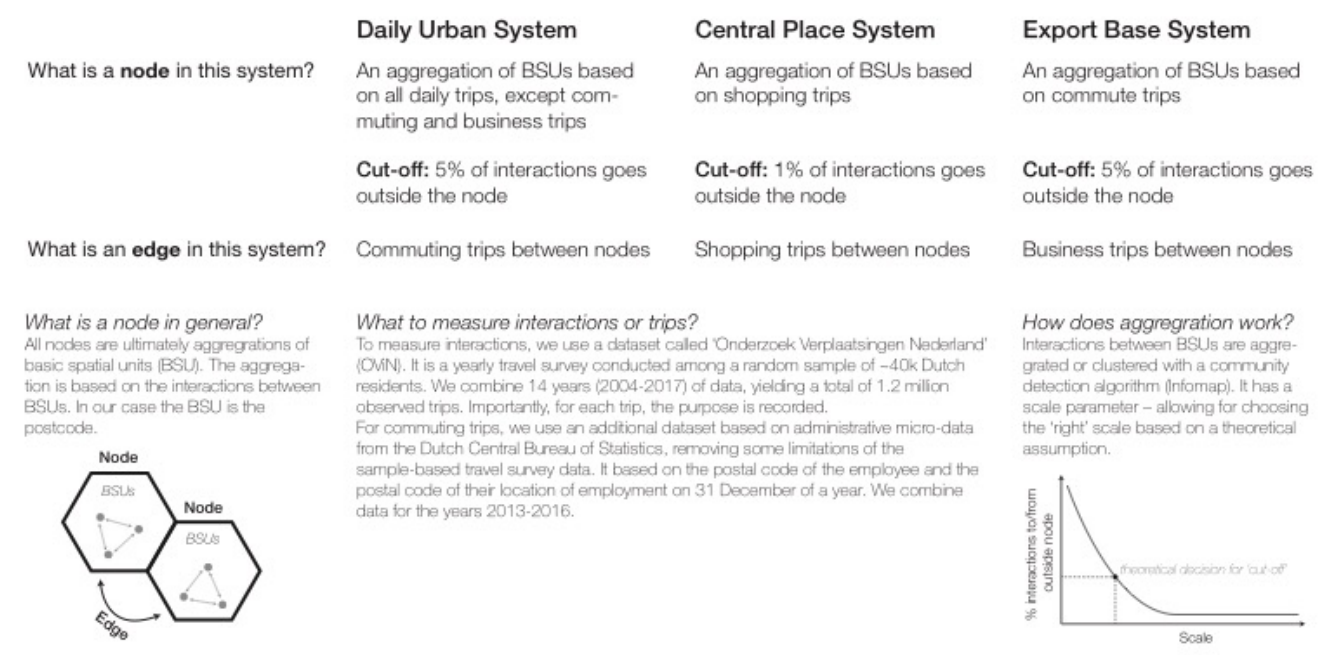

Figure 1: Overview of the operationalization of the three systems.

Calibrating the daily urban system - In the Netherlands, the term daily urban system (DUS) is traditionally used as synonym for 'city region' ('stadsgewest', comparable to what elsewhere is 
called 'labour market area' or 'travel to work area') following a practice where commuting data is used determine the boundary of the DUS nodes (Berry 1970). Although the daily routine of travelling to work is a defining part of the DUS to most households, and such data is traditionally most easily available, limiting the focus to commuting obscures the causal mechanism driving the DUS which is the total time-geographical dynamics on the household scale (Van Engelsdorp Gastelaars \& Wagenaar 1981, p. 240; De Graaf 2018). Daily urban systems emerge through the opportunities and constraints households face in organizing their daily social reproduction. This reproduction involves not just work but also education, shopping, daily recreation and coordination of the household division of labour (Ellegård \& Vilhemson 2004). This coordination process is geographically structured by the time-space constraints in which a household resides (Ellegård et al. 1977) and the bundles in that geographical structuring are a good approximation of containment. The advocacy to include the DUS as a third system in the model (Van Engelsdorp Gastelaars \& Ostendorf 1991) is based on households gaining so much mobility and choice that consumption preferences for living environments had become an autonomous factor in urban systems development. Indeed, dual income households and more complex lifestyle preferences have complicated the DUS (Dieleman \& Van Engelsdorp Gastelaars 1992; Musterd \& Van Zelm 2001; Limtanakool et al. 2009) as more disparate activities with individualized lifestyle choices have to be packed within the same time budgets.

The distinction between travel to work and the other activities is key in the operationalization of the DUS. All daily interactions except travelling to work and business trips are used to define the node of the network (based on 1.1 million observations, once weighted yielding a total of 24.7 million daily trips). Travel to work trips are then used to define the edges between nodes ${ }^{5}$. In doing so we preserve the notion of a limited action space for the daily urban system (Dijst 1999), while simultaneously making visible the imbricated daily urban system nodes that make up regional labour markets (Boussauw et al. 2018).

To aggregate interactions between basic spatial units to larger DUS nodes, we use Infomap (Rosvall et al. 2010), a community detection algorithm that uses the daily interactions described 
above to determine cohesive sets of basic spatial units that together comprise a DUS node (for a longer discussion of the algorithm and alternative approaches, see Poorthuis 2018). The Infomap algorithm has a scale parameter - referred to as Markov time - that allows the researcher to determine the size or scale of the resulting regions. There is no perfect setting here because of the node inclusivity dilemma. We initially run the algorithm for all Markov times between 0 and 6.0 (increments of 0.1) (Figure 2). Each increment returns a specific set of clusters, where generally higher Markov time yields larger clusters. Based on this, we fix the scale parameter to the Markov time where less than $5 \%$ of all daily interactions goes outside the DUS (Figure 2), which yields a total of 162 daily urban system nodes.
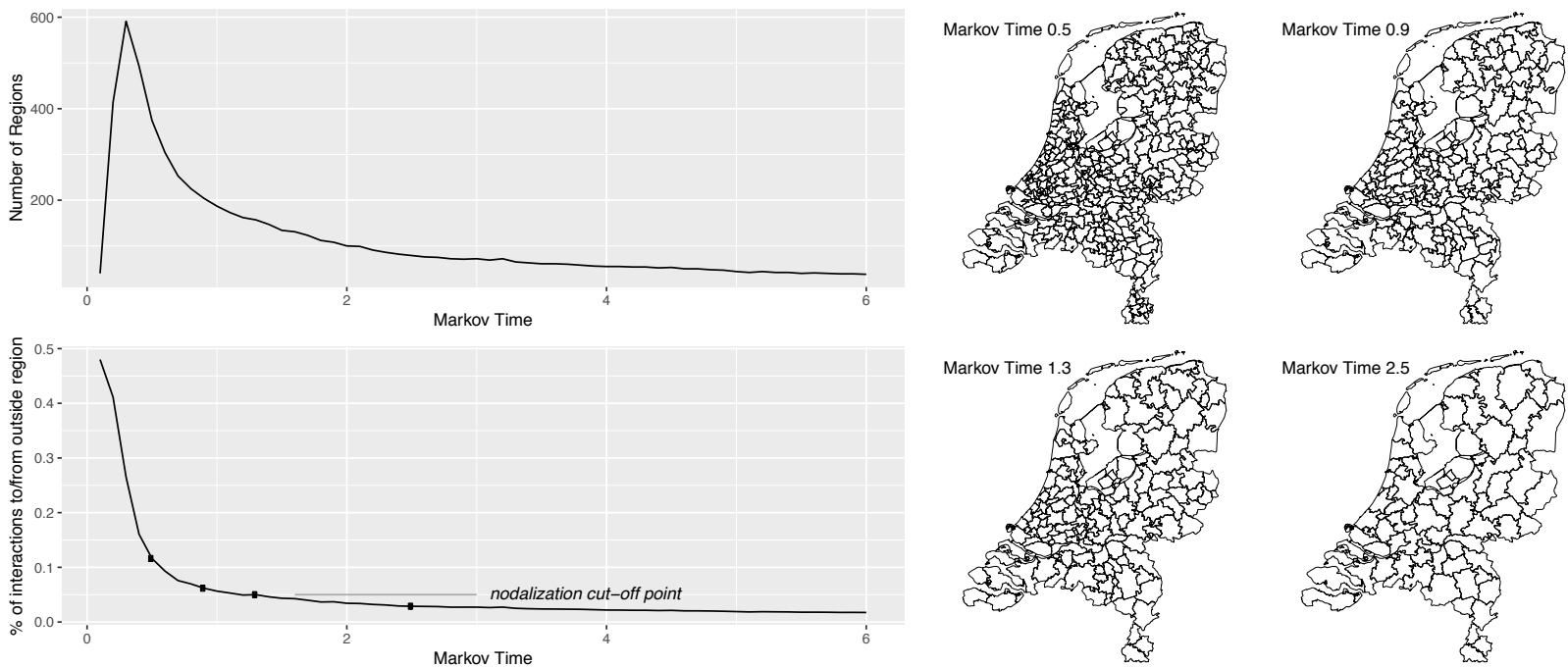

Figure 2: The Daily Urban System at different cut-off points of the scale (Markov time) parameter. 

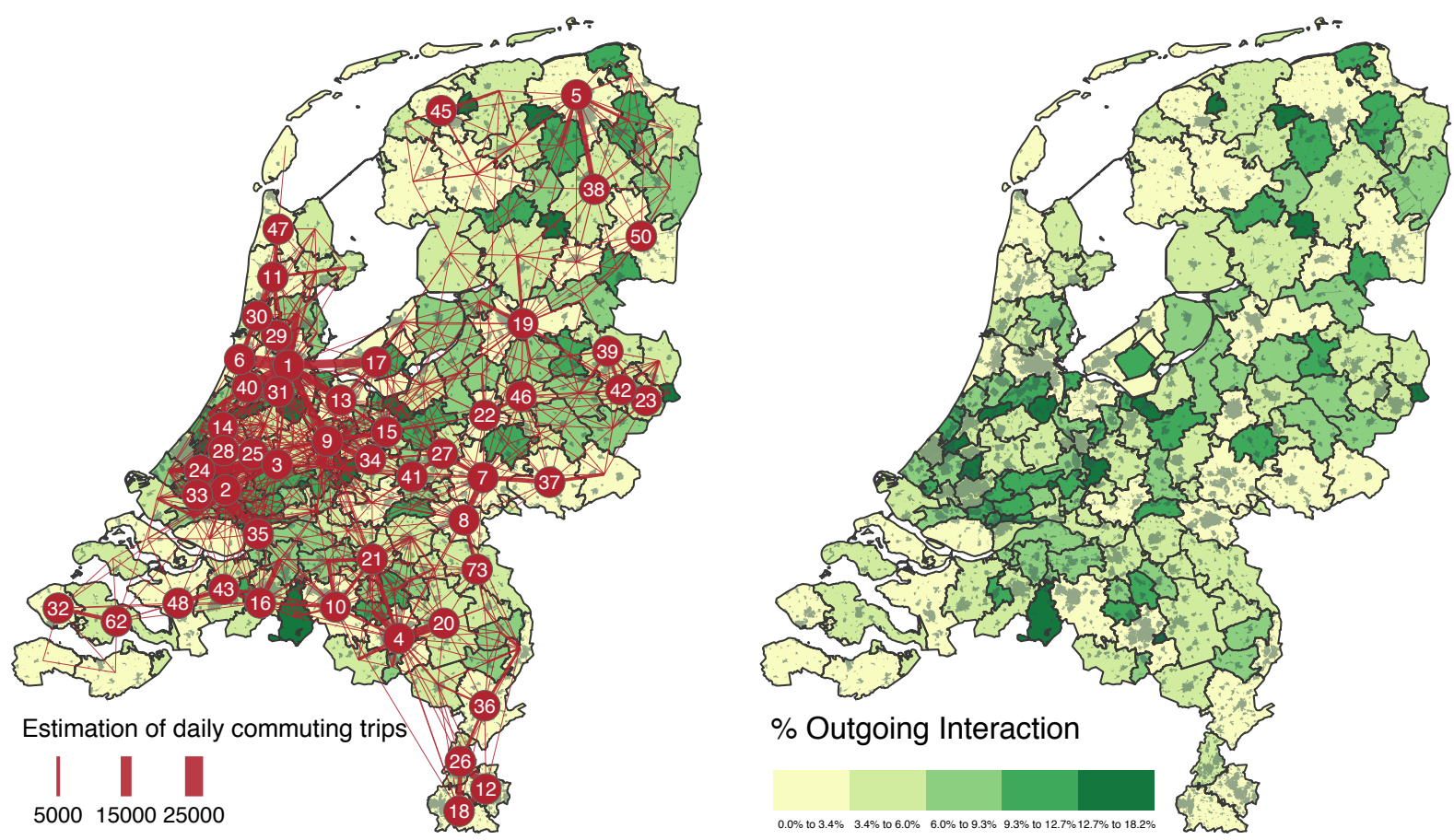

Figure 3: Daily Urban System ${ }^{6}$

Analysis of the Daily Urban System - The edges between DUS nodes (Figure 3a), reveal a pattern familiar from other Dutch labour market geographies (Limtanakool et al. 2009; Burger et al. 2014a; 2014b). We see the ring of imbricated labour markets that make up the Randstad (nodes 1, 2, 24, 9) and smaller urban networks in South Limburg $(12,18,26)$, Arnhem-Nijmegen (7-8), Twente $(23,39,42)$, the row of cities in Brabant Province $(4,10,16,21)$ and GroningenAssen $(5,38)$. In fact, the empirical data fits very well with the urban networks championed in the spatial plans from the 1990s and 2000s (Zonneveld \& Verwest 2005, pp. 210-211)

However, it is the nodal perspective (Figure $3 b$ ) that generates new insights. The nodes represent regions of daily social reproduction and their colour indicates how fuzzy the boundaries of these regions are. The higher the outgoing interaction value, the less internal cohesion that area has and the more 'porous' the boundary of the node is. The suburbs around large employment centres tend to have a high degree of outgoing interactions (and thus relatively little internal cohesion). Authors such as Phelps (2017), and Keil (2018) effectively argue that these 
'interplaces' in-between traditional cities are significant shapers of contemporary urban systems as they contribute to the urban vitality of multiple centres and tie them together. These are the nodes that perform the imbrication and thus make cities into polycentric urban regions (Boussauw et al. 2018). Moreover, these are potential places that could become "postsuburbia", a process of "rounding out of traditional suburbs into cities in function but not in form" (Phelps, 2015, p.41; cf Bontje 2004). We make the case that the spatial coherence of the urban networks that have been chronicled since the 1990s are in fact produced by the interplaces that are often looked over, but which deepen the housing and labour markets of several historically-defined cities simultaneously. The fact that these daily urban systems cannot be unambiguously assigned to a single larger city underlines that point.

Calibrating the central place system - In a detailed micro level study, Van Meeteren \& Poorthuis (2018) argue that the foundations of Christaller's (1933 [1966]) central place theory (CPT) retain contemporary validity. CPT posits that there is geographical structuring in the relation between population and the goods and services available to that population. Central functions require a minimal number of customers (the threshold) and the average customer is only willing to undertake so much effort to procure a certain central good (the range). The interplay between these two generates a causal mechanism that explains which settlements are likely to provide certain central functions to the population (Van Meeteren \& Poorthuis 2018). It has generally been acknowledged in Dutch central place studies that the boundaries of central place hinterlands are fuzzy and overlaps and complementarities occur in an automobile society (Lambooy 1969; Buursink 1971). Nevertheless, there remain zones that are underserved and overserved by central functions related to their population and distance to retail centres (Burger et al. 2014c). Resultantly, we argue that the interplay between agglomeration shadows and borrowed size (Burger et al. 2015), where it pertains to retail and amenities, i.e. central functions, are the consequence of the central place causal mechanism.

To highlight this relationship in our central place analysis we divide the procurement of central functions according to trips with a shopping motive ( 354,000 observations, once weighted 
yielding a total of 8.2 million daily trips). We repeat the same procedure as with the DUS and generate clusters for the Markov times between 0 and 6.0 and fix the scale parameter to the Markov time where less than $1 \%$ of all daily interactions goes outside the central place, which yields a total of 86 central place nodes. The remaining 1 percent of interactions is depicted as edges showing the connectivity between central places, traditionally used as an indication of urban hierarchy (Nystuen \& Dacey 1961). Contrary to the daily urban system where we have the distinction between work and non-work trips, the available data provides no similar distinction between the kind of shopping trips, which we could use to discriminate between node and edge. However, central place systems are agued to produce discrete categories (instead of a continuum) of agglomerations where higher-order centres are only visited on a very irregular basis (Saey \& Litaer, 1980). In order to highlight these urban hierarchical relations, we use the stricter $1 \%$ interaction criterion.
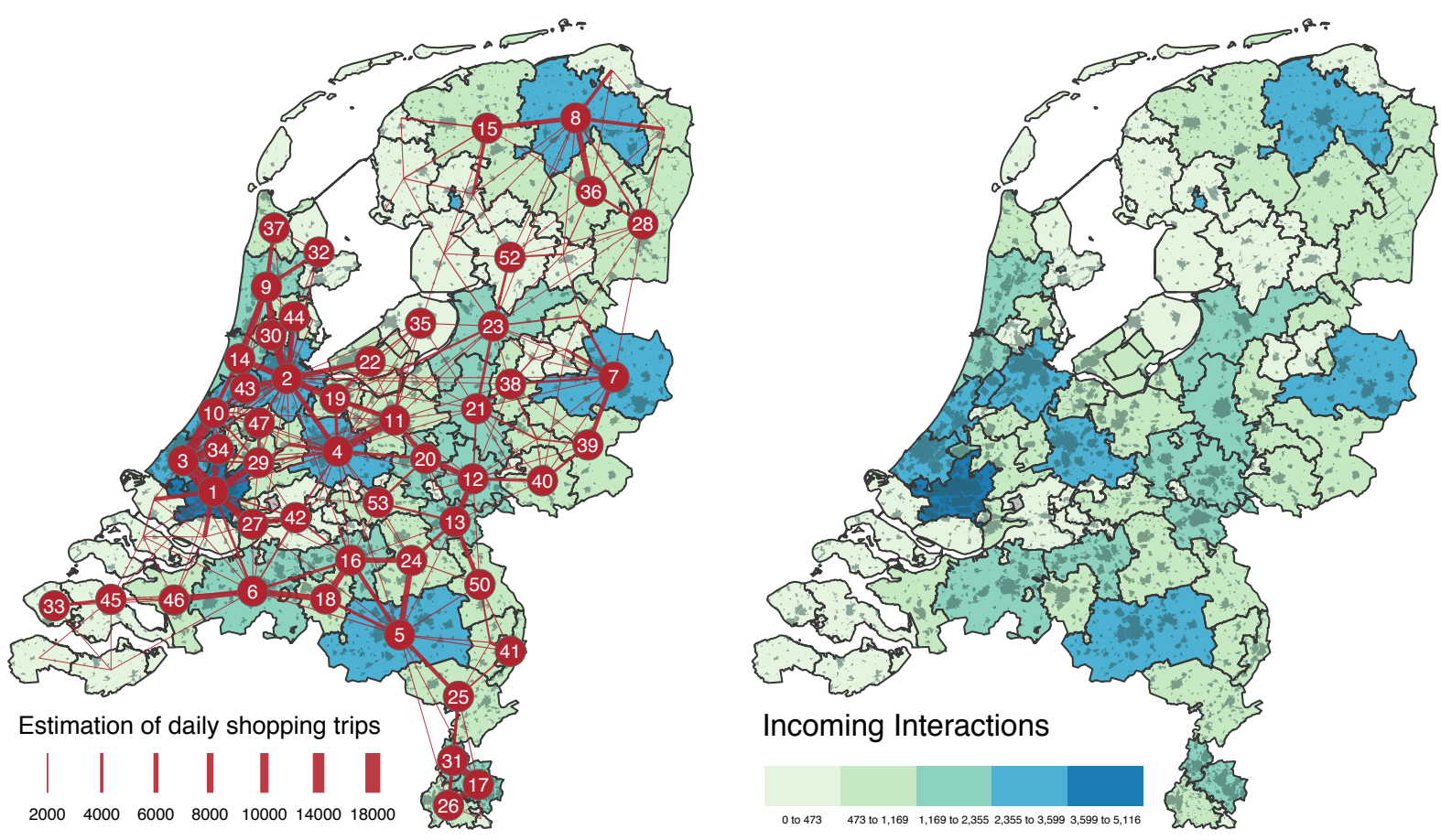

Figure 4: Central Place System 
Analysis of the central place system - The degree of incoming interactions depicted in figure $4 \mathrm{~b}$ is a good indicator of centrality as people from outside the node come to this place to shop. Together with the edges, we can estimate whether a central place node is subject to borrowed size (higher values) or an agglomeration shadow (lower values) (see Burger et al. 2015 for an elaboration of terms). The lateral networks in the central place system, where regions with lower or middle degrees of incoming interactions show mutual connectivity, support the argument for the existence of polycentric central place regions. These are likely generated by having complementary central functions (Lambooy 1969). It is remarkable, but theoretically unsurprising, that nodes with higher levels of incoming interaction are much larger than the daily urban systems that they tend to integrate, while the geography of lower level incoming interaction nodes often seems to align with daily urban systems, at least at first glance. 'Daily' shopping is integrated in daily routines while periodic purchases require travel to a different node if one does not live in a higher-level central place. Edges between higher and lower incoming interaction level nodes indicate different positions in the central place hierarchy. The existence of such a hierarchy is backed-up by examining historical path dependence. Although a detailed comparison is outside the scope of this paper, the resulting map of the Dutch central place system shows remarkable continuities with the maps published in Buursink (1971, p. 68) and Keuning (1971, p. 10). What is indicated there as hinterlands of primary central places, the largest region, largely coincides with the regions that show a group of networked nodes centred around a high incoming interaction node in this study.

Calibrating the export base system - If a global geography of interacting regions shaping the world-wide economic system is conjured (Pred 1977; Hohenberg \& Lees 1995 [1985]; Scott 1998; Taylor \& Derudder 2016), it (implicitly) refers to the export-base system (Van Meeteren 2016). Export base theory's geographical structuring mechanism is based on the idea that no region is economically autarchic (Blumenfeld 1955), resulting in geographically articulated adjustments emerging from positive or negative balances of income. If the balance of income is negative, this is geographically expressed in a combination of net population loss, austerity, and/or a financial compensation mechanism such as devaluation, borrowing money or inter-regional income 
redistribution. Inversely, if the balance of income is positive the region will gain population, a raising standard of living, and excess capital outflows (Van Meeteren 2016, p.151; Keuning, 1965, pp. 440-487 provides an elaborate application of the theory in the 1960s Netherlands). The causal mechanism of the export base system is spatially articulated through multiplier effects. As it is impossible to account for the exact location of multiplier effects and added value generated from a propulsive industry that facilitates the export base, the only way to spatially account for it is by drawing a boundary across the whole multiplier region (Tiebout 1956a). The analytical benefit is that the spatial reach of export-base regions can be calibrated through the spatial behaviour of those who produce the consumption-based multiplier effect that is generated by export base activities (Tiebout 1956a, 1956b). Consequently, the outer boundary of interlocking and imbricated daily urban systems estimates the containment of an export base system node, as that is the best-possible approximation of the spatial reach of consumption generated by export base income and its multiplier. Again, the node inclusivity dilemma requires us to be slightly less bullish as outliers could likely leave us with a single global node that says little to nothing. As such, we use commuting interactions here. Commuting data is derived from micro-level administrative data available through the Dutch Statistics Bureau (CBS). Exact residential and office location are aggregated to the postal code level, with interactions between postcodes with fewer than 10 observations suppressed in accordance with privacy regulations. Self-employed individuals and those with more than one job are excluded as well. This results in a total of a total of 3.9 million commuting relations at the postcode level. We fix the scale parameter to the Markov time where less than $5 \%$ of all daily interactions goes outside the region, which yields a total of 16 export-base system nodes.

Export base regions form the regional mosaic of the world-economy through their mutual linkages in commodity chains (Scott, 1998). There has been a longstanding tradition in geography that uses business communication linkages as proxies to understand the intensity of interactions between export base regions (Dietvorst \& Wever 1977; Pred 1977; Taylor \& Derudder 2016). Therefore, in our analysis we use the business trips within the household travel survey dataset to estimate the degree of interactions between export-base regions in the Netherlands. 

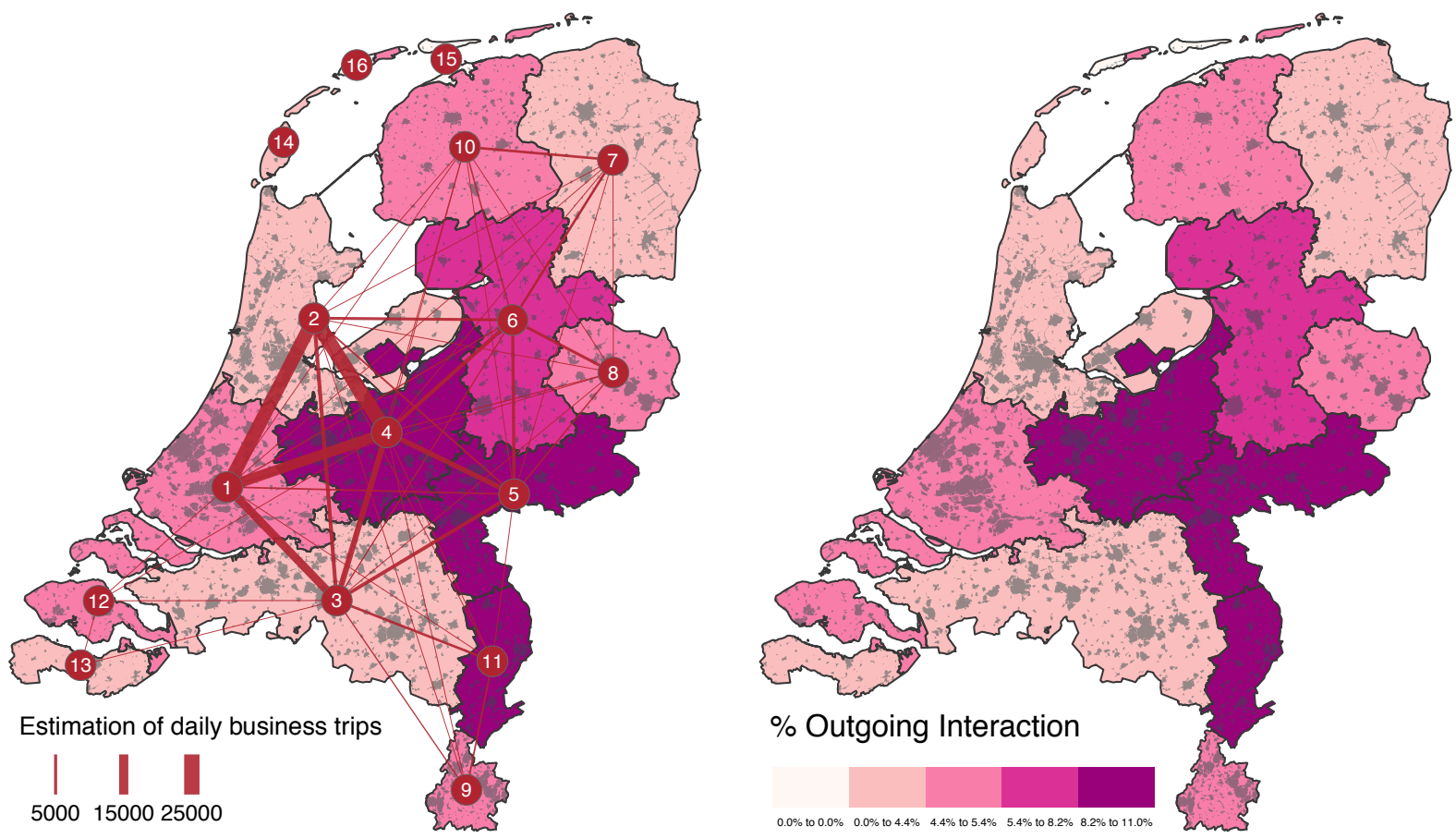

Figure 5: Export Base System

Analysis of the Export base system - When we, heeding Tiebout's (1956a, 1956b) advice, collate the imbricated daily urban system nodes in larger regions and cut them off with the algorithmic method to cope with the node inclusivity dilemma, we find that the Netherlands is subdivided in 12 major regions, and 4 smaller ones because of geographical barriers such as islands or rivers (13-16). The lighter the colour of the region, the more closed it is in terms of outgoing commuting relationships and hence less ambiguous its territorial definition. The edges in Figure 6a express the amount of business trips, giving an indication of inter-regional interdependencies.

Although we only find 12 instead of Keuning's (1965, p. 201) 20 regions (indicating a potential upscaling of economic regions in past decades), the overall structure is still largely the same. It should also be noted that the boundaries of the 12 major regions generally follow provincial administrative border. Our analysis confirms the assessment of Ritsema van Eck et al. (2006) and Burger et al. (2014b) that the Randstad is functionally divided in two economic regions, a North 
Wing (node 2) and a South Wing (1), albeit with a strong economic interdependence between them. What is interesting is where the algorithm assigns outer boundaries to the respective Randstad wings. The northern part of North Holland Province is assigned to the larger North Wing region as a significant part of Flevoland province. Another remarkable finding is the low degree of outgoing interaction from the North Wing. Such high containment in the North Wing underlines the argument that the node interacts on a higher level in the global city system rather than the rest of the country (Burger et al. 2014a, p. 836). However, the export base system analysis also confirms the main finding from the 1990s urban network literature, which asserts that the core area of the Netherlands is shifting towards the middle of the country (Priemus 1998, cf. Dietvorst \& Wever, 1977) - what Jobse \& Needham (1988) call the 'half-way-zone'. We find that the zones to the East and Southeast of the Randstad (3-6) show high levels of business trip interactions. On the outer edges of the Netherlands, we find that regions in the Northeast (7), the South (9) are relatively autarchic economic regions with a limited degree of business trip interaction underlining their divergent regional-economic profiles (Raspe \& Van den Berge 2017), a pattern also already signaled by Dietvorst \& Wever (1977). So although the export base system analysis generates a settlement structure that indicates metropolization in the centre, this is not entirely to the detriment of the economic spread effects that were predicted in the 1990s. The economic-core area of the Netherlands is an integrated set of export base regions that covers the entire centre of the map. This is exemplified by the hexagon-shaped web of thick edges with Utrecht (4) more or less at its centre.

\section{MULTIPLEXITY ANALYSIS}

Burger et al. (2014a; 2014b) analyse how urban networks are multiplex - consisting of overlapping and interconnected 'layers' or 'levels' of networks. Translated to our particular application, they argue that the configuration of the urban network depends on the criteria used for nodalization (Burger et al. 2014a, 822). Analyzing interactions in these multiplex urban networks would require multi-level modelling, where each node takes up a different position in each layer or level of the network (Ducruet \& Beaugitte 2014). Doing such a multi-level urban systems analysis would be relatively straightforward if the nodes of different urban systems have 
the same scale and shape, or if they would be neatly nested. The export base system nodes would be a spatial aggregation of the central place nodes, which in turn are an aggregation of the daily urban system nodes, which are ultimately an aggregation of basic spatial units. However, if such nestedness cannot be assumed, a whole new family of methodological problems emerges that relate to the node inclusivity problem. It is outside the scope of this paper to explore these issues in depth apart from one point: we need to know how large this methodological issue really is and whether it prevents us from conducting a comprehensive analysis of the Dutch urban system. Does this problem only relate to a few outliers, or is it fundamental to the use of urban networks as an analytical category to understand spatial economies?

To quantify the degree of overlap or nestedness between two sets of regions or clusters, we adopt the Wallace Index $\mathrm{I}^{7}$ (Wallace 1983). The Index allows us to compare two different sets of regions with a single statistic that ranges from 0 to 1 , where 1 indicates complete nesting. We can calculate this on a global level (as is visually explained in Figure 6), comparing two entire systems with each other. We can also calculate the Index on the local, or postcode, level. If we stay with the comparison between DUS and central place nodes: we compare each postcode with all other postcodes and note down whether they are in the same node within the DUS system. We then do the same for central place system, effectively creating a set of relations for each postcode, indicating whether the surrounding postcodes are contained within the same region in the two systems. The Wallace Index can then be calculated by looking at all the pairs of relations for that postcode: if a pair is in the same region in both central place and DUS, it counts as N11 (see Figure 6); if not, it counts as N10. Since we are comparing three 'nested' system, we do two comparisons (DUS to central place; and central place to export base node) and take the mean of the two indices in the maps below.

When we compare the three systems globally, the Wallace Index for DUS to central place system is 0.92 , indicating a very high degree of 'agreement' between the two systems. Similarly, the Wallace Index for central place to export base system is even higher: 0.96 . While a first conclusion 
might be that the systems are indeed nicely nested, a different picture emerges when we look at the nestedness on the local level (Figure 7).
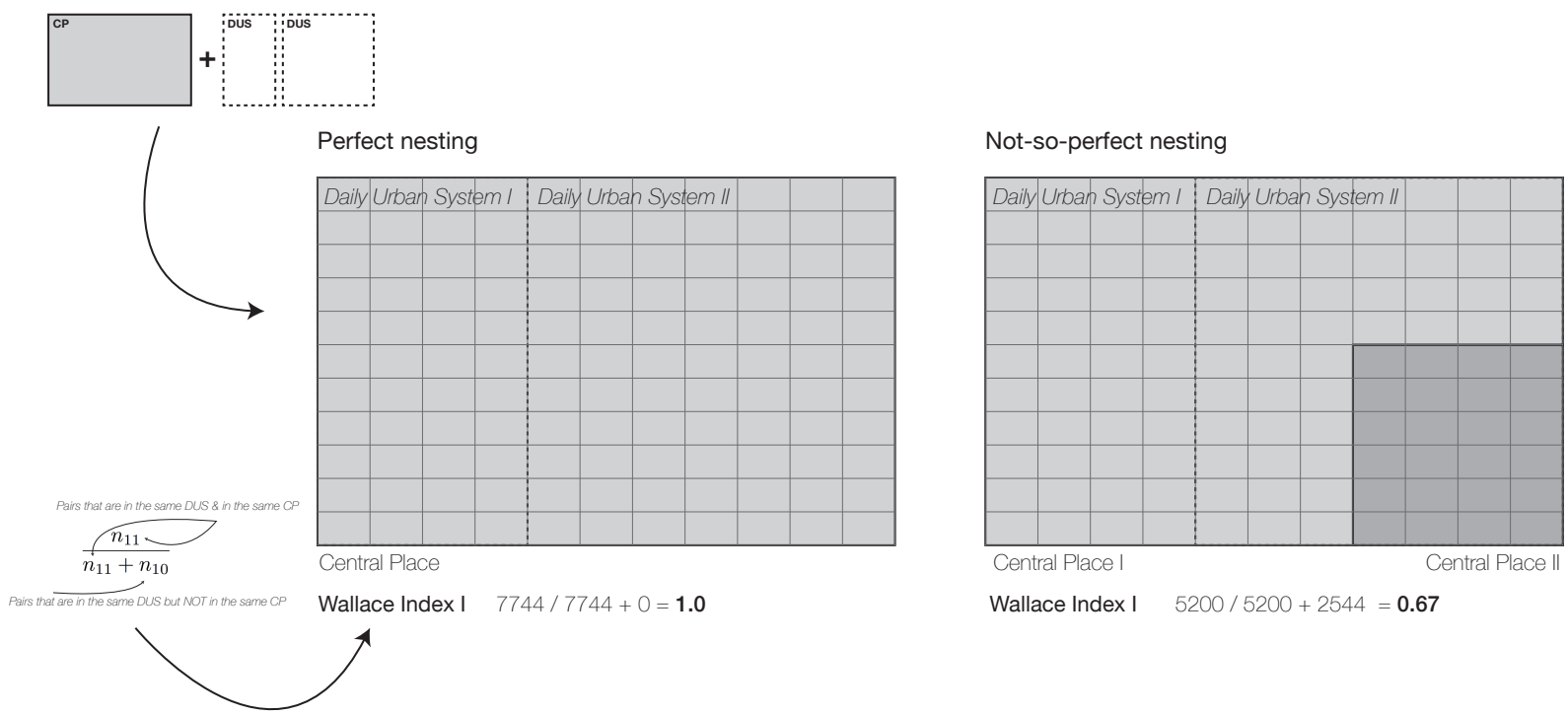

Figure 6: Overview of the Wallace Index (nestedness)
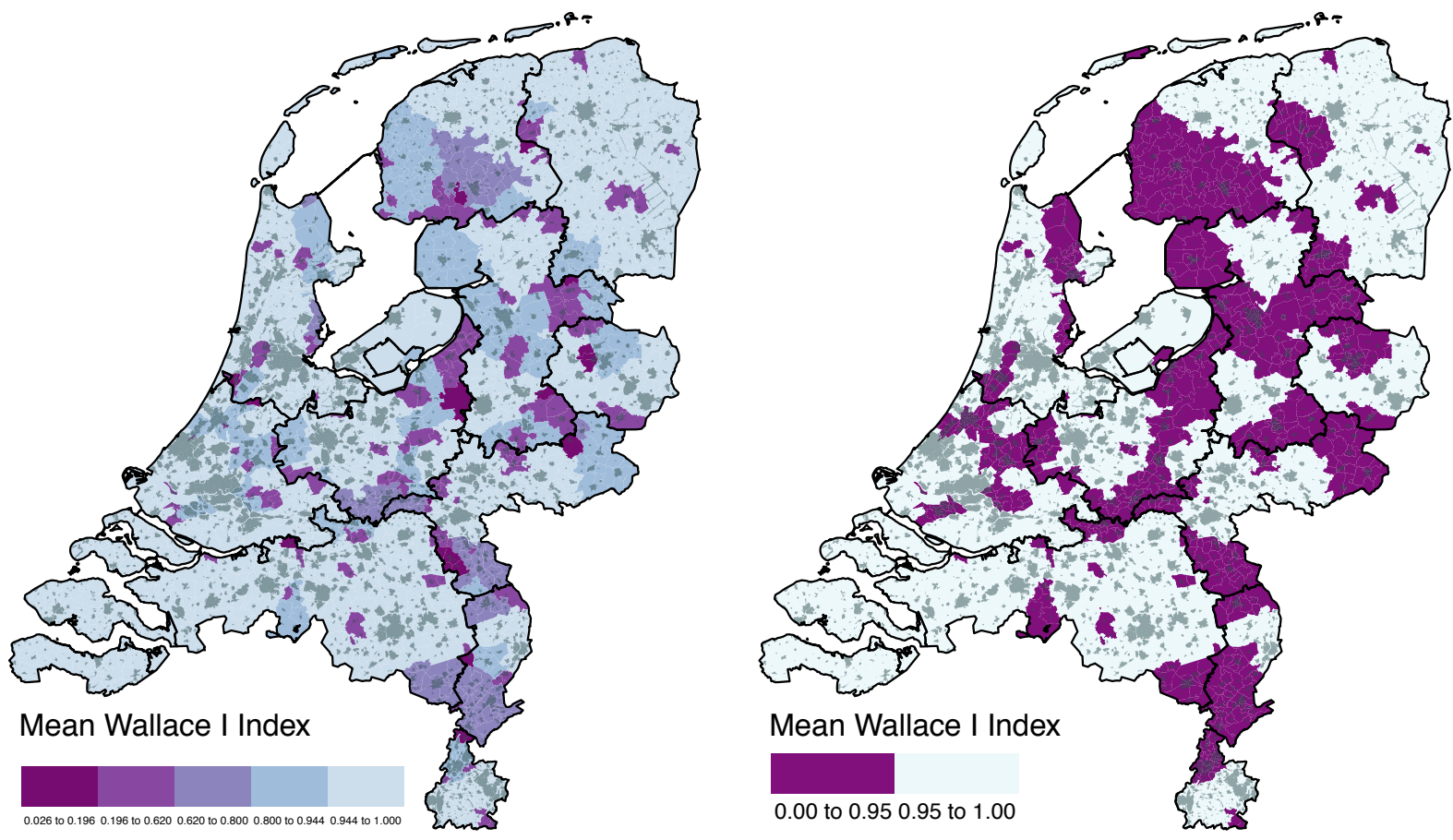

Figure 7: (Non)nestedness across the three systems 
What is beyond doubt from Figure 7 is that the compounding effects of the node inclusivity dilemma of the three urban systems impacts a significant amount of the Dutch territory and population in very specific locations. They tend to be the places on the boundary or in-between existing city regions, and are indeed interplaces in the semantic and theoretical sense of the word (Phelps, 2017). In interplaces, urban systems only partly overlap where interactions effects occur if one of the three systems expand or contract, expressed through spread and backwash effects (Taaffe et al. 1992; Van Meeteren 2016, pp. 155-158). They are the places where 'size is borrowed from' to enable higher amenity levels and divisions of labour in neighbouring settlements (Burger et al. 2015). It is important to note that while some of these places are rural or sparsely populated, this is certainly not the case across the board. The postcodes with a Wallace Index lower than 0.95 (Figure $7 b$ ) are home to 3.7 million people, representing $~ 22 \%$ of the Dutch population. They contain significant 'postsuburban' places such as the Schiphol Airport area (Bontje, 2004) and historical cities such as Leiden and Zwolle. As these places lie on the margins of the interactions between the three urban systems, their futures will be strongly dependent on further development within these interactions (Boussauw et al. 2018). It should also be noted that these interplaces are not merely an artefact of, for example, the node-inclusivity parameter used for each of the three systems (see Figure 1): the Wallace index remains stable across different values for this cut-off parameter.

\section{CONCLUSION}

Geography has a long tradition of understanding settlement geographies in terms of functional urban networks. This tradition is historically pronounced in Dutch academia and spatial practice and helps explains the prominence of Dutch network thinking in the international literature and policy discourse. Over time such network thinking has produced both centrifugal and centripetal geographies, emphasising larger and smaller spatial units. As this theorizing has a much longer history than empirical testing, such variability can be understood. A first aim of this paper was to provide a genealogy of the Dutch urban network and systems traditions. The subsequent network analysis applied these ideas, synthesized in the three-systems model, to examine multiplexity in Dutch urban networks using data and analytical methods that were unavailable in the past. The 
results of that analysis underline the slipperiness of formulating urbanization policy in monolithic terms. Our analysis simultaneously confirms the gradual extension of the Dutch metropolitan core area into the 'half-way zone' as was predicted in the 1990s, while also affirming the resurgent urban primacy of many historical central places that is often considered the antithesis to that expansion. The study confirms the primacy of the Randstad in the Netherlands, decisively comprised of two wings, but with strong interdependencies between them. Although we underline the centrality of the Amsterdam metropolitan region in the Dutch urban system, the analysis also shows that the functional urban area implicated by that analysis bears little resemblance with what historically would be considered 'Amsterdam'. Haarlem, Alkmaar, Enkhuizen, Almere, and even Den Helder are part of the same functional urban area based on an export-base logic (Figure 5), which is the most appropriate urban system to compare settlements in global urban networks.

Secondly, our analysis laid bare a yet-unsolved methodological issue that arises when taking a multi-level approach and analysing the interdependencies and multiplexity in urban networks. We argue, based on the Dutch settlement geography tradition, that each of the three urban systems has to be nodalized at a different scale. We propose the term 'node-inclusivity dilemma' to discuss the trade-offs that have to be considered in nodalizing these spatial fields. Resultantly, the places where nodes do not nest, the seams between different urban systems, are where the most important reverberations of interaction effects between expanding or contracting urban systems are found. Ironically, it is these interplaces that are often rendered 'fly-over territory' in network-conceptions of the world and are argued to be irrelevant for urban networks (Veltz, 1996), they are places that do not matter (Rodríguez-Pose 2018). Nevertheless, on the scale of the Netherlands, we would like to contend that these places are at the boundaries of agglomeration economies, and both expanding and contracting settlements will invoke their functional expression on the housing and labour markets in these interplaces. Therefore, when urban economists, economic geographers and spatial planners desire to optimize agglomeration economies, careful understanding and management of the tensions between containment and 
connectivity in urban systems, and thus the dynamics of interplaces, deserve our undivided attention.

\section{REFERENCES}

AMIN, A. \& S. GRAHAM (1997). The Ordinary City. Transactions of the Institute of British Geographers, NS22, pp. 411-429.

ATZEMA, O.A.L.C. (1999). Netwerksteden: Net van Werksteden. In: F. DIELEMAN \& S. MUSTERD, eds., Voorbij de Compacte Stad, pp. 121-139. Assen: Van Gorcum.

BATTEN, D.F. (1995). Network Cities: Creative Urban Agglomerations for the 21st Century. Urban Studies, 32, pp. 313-327.

BERRY, B.J.L. (1970). The Geography of the United States in the Year 2000. Transactions of the Institute of British Geographers, 51, pp. 21-53.

BLUMENFELD, H. (1955). The Economic Base of the Metropolis: Critical Remarks on the "BasicNonbasic" Concept. Journal of the American Institute of Planners, 21, pp. 114-132.

BONTJE, M. (2001). The Challenge of Planned Urbanisation. (Ph.D. thesis, University of Amsterdam).

BONTJE, M. (2004). From suburbia to post-suburbia in the Netherlands: Potentials and threats for sustainable regional development. Journal of Housing and the Built Environment, 19, pp. 25-47.

BOUSSAUW, K., M. VAN MEeTEREN, J. SANSEN, E.J. MeIJERS, T. STORME, E. LOUW, B. DERUdDER \& F. WITLOX (2018). Planning for Agglomeration Economies in a Polycentric Region: Envisioning an Efficient Metropolitan Core Area in Flanders. European Journal of Spatial Development, 69, pp. 1-26.

BURGER, M.J., B. VAN DER KNAAP \& R.S. WALL (2014a). Polycentricity and the Multiplexity of Urban Networks, European Planning Studies, 22, pp. 816-840.

BURGER, M.J., E.J. MEIJERS \& F.G. VAN OORT(2014b). Multiple Perspectives on Functional Coherence: Heterogeneity and Multiplexity in the Randstad. Tijdschrift voor Economische en Sociale Geografie, 105, pp. 444-464.

BURGer, M.J., E.J. MEIJERS \& F.G. VAN OORT (2014c). Regional Spatial Structure and Retail Amenities in the Netherlands. Regional Studies, 48, pp. 1997-1992. 
BURGeR, M.J., E.J. MEIJERS, M.M. HOOgERBRUgGe \& J. MASIP TRESSERRA (2015). Borrowed Size, Agglomeration Shadows and Cultural Amenities in North-West Europe, European Planning Studies, 23, pp. 1090-1109.

BUURSINK, J. (1971). De Nederlandse Hiërarchie der Regionale Centra: Een Institutionele Wijze van Hierarchisering. Tijdschrift voor Economische en Sociale Geografie, 62, pp. 67-81.

CHISHOLM, M. (1975) Human Geography: Evolution or Revolution. Harmondsworth: Penguin Books.

CHRISTAlleR, W.(1966 [1933]). Central Places in Southern Germany. Eaglewood Cliffs: Prentice Hall.

COLBY, C.C. (1933). Centrifugal and Centripetal Forces in Urban Geography. Annals of the Association of American Geographers, 23, pp. 1-20.

CORTIE, C., DIJST, M., \& OSTENDORF, W. (1992). The Randstad a metropolis? Tijdschrift voor Economische en Sociale Geografie, 83, pp. 278-288.

DE GRAAF, E.A. (2018). Daily Urban Systems Explained from the Household Perspective: An Exploratory Research on How the Spatial Interactions of the Individual Households Shape the Structure of Daily Urban Systems. European Planning Studies, 27, 106-125.

DE SMIDT, M. (1983). Dutch Economic Geography in Retrospect. Tijdschrift voor Economische en Sociale Geografie, 74, pp. 344-357.

DEMATTEIS, G. (1988). The Weak Metropolis. In: L. MAZZA, ed., World Cities and the Future of the Metropolis, pp. 121-133. Milano: Electa-XVII Triennale.

DIELEMAN, F.M. \& R. VAN ENGELSDORP GASTELAARS (1992). Housing and Physical Planning. In: F.M. DIELEMAN \& S. MUSTERD, eds., The Randstad: A Research and Policy Laboratory, pp. 6596. Dordrecht: Kluwer Academic.

DIETVORST, A.G.J., \& WEVER, E. (1977). Changes in the pattern of information exchange in the Netherlands, 1967-1974. Tijdschrift voor Economische en Sociale Geografie, 68, pp. 7282.

DIJST, M. (1999). Action Apace as a Planning Concept in Spatial Planning. Netherlands Journal of Housing and the Built Environment, 14, pp. 163-182.

DUCRUET, C. \& L. BEAUGUITTE (2014). Spatial Science and Network Science: Review and Outcomes of a Complex Relationship. Networks and Spatial Economics, 14, pp. 297-316. 
ELLEGÅRD, K., T. HÄGERSTRAND \& B. LENNTORP (1977). Activity Organization and the Generation of Daily Travel: Two Future Alternatives. Economic Geography, 53, pp. 126-152.

ELLEGÅRD, K. \& B. VILHELMSON, (2004). Home as a Pocket of Local Order: Everyday Activities and the Friction of Distance. Geografiska Annaler: Series B, Human Geography, 86, pp. 281296.

FOWLKES, E.B. \& C.L. MALLOWS (1983). A Method for Comparing Two Hierarchical Clusterings. Journal of the American Statistical Association, 78, pp. 553-569.

HAGGETT, P. (1965). Locational Analysis in Human Geography. London: Arnold

HAJER, M.A. \& ZONNEVELD, W. (2000). Spatial Planning in the Network Society-Rethinking the Principles of Planning in the Netherlands. European Planning Studies, 8, pp. 337-355.

HARRIS, R., JOHNSTON, R., \& BURGESS, S. (2016). Tangled Spaghetti: Modelling the Core Catchment Areas of London's Secondary Schools. Environment and Planning A, 48, pp. 1681-1683.

HOEKVELD, G.A. (1968). Over de theorie en stand van de stadsgeografie. Tijdschrift voor Economische en Sociale Geografie, 59, 1-12.

HOHENBERG, P.M. \& L.H. LEES (1995 [1985]). The Making of Urban Europe, 1000-1994. Cambridge MA: Harvard University Press.

JOBSE, R.B. \& B. NEEDHAM (1988) The Economic Future of the Randstad, Holland. Urban Studies, 25, pp. 282-296.

KEIL, R. (2017). Suburban Planet: Making the World Urban From the Outside in. Hoboken: John Wiley \& Sons.

KEUNING, H.J. \& DE VOOYS A. (1964) Activities in the Field of Economic Regionalization in The Netherlands. Geographia Polonica 4, pp. 105-115.

KEUNING H.J (1965). Het Nederlandse Volk in zijn Woongebied, Tweede Uitgave. Den Haag: Leopold.

KEUNING, H.J. (1971). Spreiding en Hiërarchie van de Nederlandse Verzorgingscentra op de Grondslag van hun Winkelapparaat. Tijdschrift voor Economische en Sociale Geografie, 62, pp. 3-17.

LAMBOOY, J.G. (1969). City and City Region in the Perspective of Hierarchy and Complementarity. Tijdschrift voor Economische en Sociale Geografie, 60, pp. 141-154. 
LAMBREGTS, B., R. KLOOSTERMAN, VAN DER WERFF, M., R. RÖLING, R. \& L. KAPOEN (2006). Randstad Holland: Multiple faces of a Polycentric Role Model. In: P. HALL \& K. PAIN, eds., pp. 137145. The Polycentric Metropolis: Learning From Mega-City Regions in Europe. London: Earthscan.

LANG, R.E. \& P.L. KNOX (2009). The New Metropolis: Rethinking Megalopolis. Regional Studies, 43, pp. 789-802.

LIMTANAKOOL, N., T. SCHWANEN \& M. DIJST (2009). Developments in the Dutch Urban System on the Basis of Flows. Regional Studies, 43, pp. 179-196.

LYNCH, K. (1961). The Pattern of the Metropolis. Daedalus, 90, pp. 79-98.

MUSTERD, S. \& I. VAN ZELM (2001). Polycentricity, Households and the Identity of Places. Urban Studies, 38, pp. 679-696.

NEAL, Z.P. (2012). The Connected City. How Networks are Shaping the Modern Metropolis. London and New York: Routledge.

NYSTUEN, J.D. \& M.F. DACEY (1961). A Graph Theory Interpretation of Nodal Regions. Papers and Proceedings of the Regional Science Association, 7, pp. 29-42.

OPENSHAW, S. (1977). A Geographical Solution to Scale and Aggregation Problems in RegionBuilding, Partitioning and Spatial Modelling. Transactions of the Institute of British Geographers, NS2, pp. 459-472

PHELPS, N.A. (2015). Sequel to Suburbia: Glimpses of America's Post-Suburban Future. Cambidge MA: MIT Press.

PHELPS, N.A. (2017). Interplaces: An Economic Geography of the Inter-urban and International Economies. Oxford: Oxford University Press.

POORTHUIS, A. (2018). How to Draw a Neighborhood? The Potential of Big Data, Regionalization, and Community Detection for Understanding the Heterogeneous Nature of Urban Neighborhoods. Geographical Analysis, 50, pp. 182-203.

PRED, A.R. (1977). City-Systems in Advanced Economies. London: Hutchinson \& Co.

PRED, A.R. (1984). Place as Historically Contingent Process: Structuration and the Time-geography of Becoming Places. Annals of the Association of American Geographers, 74, pp. 279-297.

PRIEMUS, H. (1998). The Randstad and the Central Netherlands Urban Ring: Planners Waver Between Two Concepts. European Planning Studies, 6, pp. 443-455. 
PRIEMUS, H. (2004). Spatial Memorandum 2004: A Turning Point in the Netherlands' Spatial Development Policy. Tijdschrift voor Economische en Sociale Geografie, 95, pp. 578-583.

RASPE, O. \& M. VAN DEN BERGE, M. (2017). Regionaal-Economische Groei in Nederland. Een Typologie van Regio's. Den Haag: Planbureau voor de Leefomgeving.

RITSEMA VAN ECK, R., F.G. VAN OORT, O. RASPE, F. DAALHUIZEN \& J. VAN BRUSSEL (2006). Vele Steden Maken nog geen Randstad. Rotterdam/Den Haag: NAl Uitgevers / Ruimtelijk Planbureau.

RODRIGUEZ-POSE, A. (2018). The Revenge of the Places that don't Matter (And what to do About It). Cambridge Journal of Regions, Economy and Society, 11, pp. 189-209.

ROSVALL, M., D AXELSSON \& C.T. BERGSTROM (2010). The Map Equation. The European Physical Journal Special Topics, 178, pp. 13-23.

SEAY, P. (1970). The Geographical Outlook. Bulletin de la Société Belge d'Etudes Géographiques / Tijdschrift van de Belgische Vereniging voor Aardrijkskundige Studies, 39, 243-276.

SAEY, P., \& LIETAER, M. (1980). Research Note: Consumer Profiles and Central Place Theory. Tijdschrift voor Economische en Sociale Geografie, 71, pp. 180-186.

SCHWANEN, T., F.M. DIELEMAN \& M. DIJST (2001). Travel Behaviour in Dutch Monocentric and Policentric Urban Systems. Journal of Transport Geography, 9, pp. 173-186.

SCOTT, A.J. (1998). Regions and the World Economy. Oxford: Oxford University Press

SHELTON, T \& POORTHUIS, A (2019). The Nature of Neighborhoods: Using Big Data to Rethink the Geographies of Atlanta's Neighborhood Planning Unit System. Annals of the American Association of Geographers, 109, pp. 1341-1361.

STEIGENGA, W. (1972). Randstad Holland: Concept in Evolution. Tijdschrift voor Economische en Sociale Geografie, 63, pp. 149-161.

TAAFFE, E.J., S. KRAKOVER \& H.L. GAUTHIER (1992). Interactions Between Spread-and-Backwash, Population Turnaround and Corridor Effects in the Inter-Metropolitan Periphery: A Case Study. Urban Geography, 13, pp 503-533.

TAYLOR, P.J. \& B. DERUDDER (2016). World City Network, 2nd Edition. London and New York: Routledge.

THISSEN, F. (1995). Bewoners en Nederzettingen in Zeeland. Op Weg naar een Nieuwe Verscheidenheid. Utrecht en Amsterdam: Nederlandse Geografische Studies / KNAG. 
TIEBOUT, C.M. (1956a). The Urban Economic Base Reconsidered. Land Economics, 32, pp. 95- 99.

TIEBOUT, C.M. (1956b). Exports and Regional Economic Growth. Journal of Political Economy, 64, pp. 160-164.

VAN DER BURG, A.J. \& F.M. DIELEMAN (2004). Dutch Urbanization Policies from 'Compact City' to "Urban Network." Tijdschrift voor Economische en Sociale Geografie, 95, 108-116.

VAN DER KNAAP, B. (1980). Population Growth and Urban Systems Development: A case Study. Dordrecht: Martinus Nijhoff Publishing.

VAN DER LAAN, L. (1998). Changing Urban Systems: An Empirical Analysis at Two Spatial Levels. Regional Studies, 32, pp. 235-247.

VAN ENGELSDORP GASTELAARS, R. \& W. OSTENDORF (1986). The Dutch Urban System in Transition: From a Productive to a Consumptive Order? In: J.G. BORCHERT, L.S. BOURNE \& R. SINCLAIR, eds., Urban Systems in Transition, pp. 231-242. Amsterdam/Utrecht: KNAG/Geografisch Instituut Rijksuniversiteit Utrecht.

VAN ENGELSDORP GASTELAARS, R. \& W. OSTENDORF (1991). New Towns: The Beginning and end of a New Urban Reality in the Netherlands. In: M.J. BANNON, L.S. BOURNE, \& R. SINCLAIR (Eds.), Urbanization and Urban Development: Recent Trends in a Global Context, pp. 240249. Dublin: Services Industry centre.

VAN ENGELSDORP GASTELAARS, E \& M. WAGENAAR (1981). The rise of the 'Randstad', 1815-1930. In H. SCHMAL (Ed.) Patterns of European Urbaniszation Since 1500, pp. 231-248 London: Croom Helm.

VAN GINKEL, H. (1983). Mirror of a changing society. Tijdschrift voor Economische en Sociale Geografie, 74(5), 358-366.

VAN PAASSEN, C. (1962). Geografische Structurering en Oecologisch Complex: Een Bijdrage tot Gociaal-Geografische Theorie-Vorming. Tijdschrift Van Het Koninklijk Nederlandsch Aardrijkskunde Genootschap, 79, 215-233.

VAN PAASSEN, C. (1965). Over Vormverandering in de Sociale Geografie.. Groningen: JB wolters.

VAN MEeTEREN, M. (2016). From Polycentricity to Renovated Urban Systems Theory: Explaining Belgian Settlement Geographies. (PhD thesis: Ghent University).

VAN MEETEREN, M. (2019). Urban System. In: A. Orum, ed., Wiley Blackwell Encyclopedia of Urban and Regional Studies. 
VAN MEETEREN, M., K. BOUSSAUW, B. DERUDDER \& F. WITLOX (2016a). Flemish Diamond or ABCAxis? The Spatial Structure of the Belgian Metropolitan Area, European Planning Studies, 24, pp. 974-995.

VAN MEeTEREN, M., Z.P. NEAL \& B. DeRUdDER (2016b). Disentangling Agglomeration and Network Externalities: A Conceptual typology. Papers in Regional Science, 95, pp. 61-80.

VAN MeEteren, M., \& A. POORTHUIS (2018). Christaller and "Big Data": Recalibrating Central Place Theory via the Geoweb. Urban Geography, 39, pp. 122-148.

VAN OORT, F.G., E.J. MEIJERS, M. ThISSEN, M.M. HOOgERBRUgGe \& M.J. BURger (2015). De Concurrentiepositie van Nederlandse Steden: Van Agglomeratiekracht naar Netwerkkracht. Den Haag: Platform 31.

VAN WEESEP, J. \& D. VAN DER VAART (1988). A new Programme of Urban Research in the Netherlands. International Journal of Urban and Regional Research, 12, pp. 139-145.

VELTZ, P. (1996). Mondialisation. Villes et territoires. L'Économie d'Archipel. Paris: Presses Universitaires de France.

VerhetSEL, A., J. BeCKERS, J., \& M. DE MEYERE (2018). Assessing Daily Urban Systems: A Heterogeneous Commuting Network Approach. Networks and Spatial Economics, 31.

WALLACE, D.L. (1983) A Method for Comparing Two Hierarchical Clusterings: Comment. Journal of the American Statistical Association, 78, pp. 569-57

ZONNEVELD, W., \& VERWEST, F. (2005). Tussen Droom en Retoriek: De Conceptualisering van Ruimte in de Nederlandse Planning. Rotterdam/Den Haag: NAI Uitgevers / Ruimtelijk Planbureau.

\footnotetext{
${ }^{1}$ Hohenberg and Hollen-lees (1994 [1985]) use the term 'network system' for the export-base system, a term adopted in early versions of the three-systems model. Van Meeteren (2016) argues that the network system is derived from the theoretical underpinnings of export base theory. To prevent confusion with other uses of the term 'network' in this paper, we adopt the term 'export-base system' here.

${ }^{2}$ Known locally as 'de bollenkubus' based on its representation of the urban system as an 'molecule of balls connected by tubes'

${ }^{3}$ From 2004-2009, the travel survey was conducted by Rijkswaterstaat under the name 'Mobiliteitsonderzoek Nederland' (MON). Since 2010, the survey is conducted by the Central Statistics Bureau under the name 'Onderzoek Verplaatsingen Nederland' (OViN).
} 
${ }^{4}$ This is lower than the total amount of trips happening on a given day (roughly 43 million trips) because not all trips recorded in the travel survey have a known postcode for both the start and end point. Additionally, we filter out all connections between pairs of postcodes with 5 or fewer observations.

${ }^{5}$ For travel-to-work interactions, we use an additional dataset based on administrative micro-data made available by the Dutch Central Bureau of Statistics, removing some limitations of the sample-based travel survey data. This dataset is based on the postal code of the employee and the postal code of their location of employment on 31 December of a year. We combine data for the years 2013-2016 and filter out all interactions between pairs of postcodes with 10 or fewer observations (due to privacy regulations).

${ }^{6}$ To aid in reading the maps, we label the 50 nodes with the highest number of interaction within the node.

${ }^{7}$ In this 1983 Comment (a response to Fowlkes \& Mallow's (1983) method to compare hierarchical cluster sets) Wallace refers to this statistic as $B^{\prime}$. In this paper, we refer to this measure as Wallace Index I 